\title{
Production scale purification of Ge-68 and Zn-65 from irradiated gallium metal
}

Jonathan M. Fitzsimmons, ${ }^{*}$ Leonard Mausner

Brookhaven National Laboratory, Bldg 801, Upton, NY 11973, USA

\begin{abstract}
Germanium-68 (Ge-68) is produced by proton irradiation of a gallium metal target, purified by organic extraction and used in a medical isotope generator to produce Gallium-68 PET imaging agents. The purpose of this work was to implement a production scale separation of Ge-68 and Zn-65 that does not use organic solvents and uses a limited number of columns. The current separation approach was modified to use AG1 resin and/or Sephadex ${ }^{\circledR}$ G25 with zinc spikes to purify Ge-68 with near quantitative recovery. The purified Ge-68 meets DOE specifications. Methods utilizing zinc spikes resulted in the purist Ge68 produced at Brookhaven National Lab with no other impurities by ICP-OES. During process optimization approximately $2.5 \mathrm{Ci}$ of $\mathrm{Ge}-68$ was purified utilizing the different processing methods, and the material was sold to the Nuclear Medicine community between 2012-2013.
\end{abstract}

\footnotetext{
Key words: Gallium-68 / ${ }^{68} \mathrm{Ga} /$ Germanium-68 / ${ }^{68} \mathrm{Ge} /$ Radiochemical separation

*Corresponding author. Current address: Brookhaven National Laboratory, Bldg 801, Upton, NY 11973, USA. E-mail: jfitzsimmons@bnl.gov
} 


\section{Introduction}

Germanium-68 $\left({ }^{68} \mathrm{Ge}\right)$ has been used in the development and marketing of the ${ }^{68} \mathrm{Ge} /$ gallium-68 $\left({ }^{68} \mathrm{Ga}\right)$ medical isotope generator. ${ }^{1,2}{ }^{68} \mathrm{Ge}$ has a long half-life ( $T_{1 / 2}=271$ days $)$ and decays by electron capture to ${ }^{68} \mathrm{Ga}\left(T_{1 / 2}=68.1 \mathrm{~min}\right)$. There are no ${ }^{68} \mathrm{Ga}$ imaging agents approved for routine clinical use for PET imaging in the United States. However, ${ }^{68}$ Ga-DOTATOC recently received FDA orphan drug designation for neuroendocrine tumor management, and the imaging agent will be fast tracked for approval. ${ }^{3}$ Due to the short half-life of ${ }^{68} \mathrm{Ga}$, the synthesis of ${ }^{68} \mathrm{Ga}$ imaging agents utilize automated systems. In June 2013 Applied Radiation and Isotopes dedicated a special issue to ${ }^{68} \mathrm{Ga}$ that covered clinical applications of ${ }^{68} \mathrm{Ga},{ }^{4}$ new ${ }^{68} \mathrm{Ga}$ imaging agents, ${ }^{5} \quad{ }^{68} \mathrm{Ge} /{ }^{68} \mathrm{Ga}$ generators, ${ }^{2}$ automated synthesis utilizing synthesis modules, ${ }^{6}$ and dosimetry of ${ }^{68} \mathrm{Ga}$-labeled compounds. ${ }^{7}$

At Brookhaven National Laboratory (BNL) ${ }^{68} \mathrm{Ge}$ is produced at the Brookhaven Linac Isotope producer (BLIP) by irradiating $~ 50-100$ grams of natural Ga targets with a $\sim 25 \mathrm{MeV}$ protons beam. ${ }^{8}$ At Los Alamos National Laboratory ${ }^{68} \mathrm{Ge}$ is produced as a spallation product after proton irradiation of molybdenum or rubidium. ${ }^{9}$ The primary long lived contaminant is ${ }^{65} \mathrm{Zn}$ with a halflife of 244 days. The ${ }^{65} \mathrm{Zn}$ is coproduced in a radioactivity ratio of $\sim 4 / 1{ }^{68} \mathrm{Ge} /{ }^{65} \mathrm{Zn}$ at the end of bombardment (EOB). The large gallium mass in the target, radioactive zinc and cobalt species must be removed from the ${ }^{68} \mathrm{Ge}$ in order to produce ${ }^{68} \mathrm{Ge}$ suitable for a ${ }^{68} \mathrm{Ge} /{ }^{68} \mathrm{Ga}$ generator for human use. 
Various prior attempts have been made for the separation of ${ }^{68} \mathrm{Ge}$ from irradiated natural gallium and they focus on three separation approaches: liquid/liquid extraction, liquid/gas distillation, and liquid resin separation. ${ }^{10}$ Germanium and gallium tetrachloride are both extremely volatile, ${ }^{10}$ and the volatile species have been used in distillation approaches for the separation of ${ }^{68} \mathrm{Ge}$ from the other metals. This approach can lead to losses of ${ }^{68} \mathrm{Ge}$ if the distillation fittings leak and can cause contamination problems. One approach used at BNL to isolate ${ }^{68} \mathrm{Ge}$ from the target material starts with leaching the ${ }^{68} \mathrm{Ge}$ from the gallium with $4 \mathrm{M} \mathrm{HCl}$ and $\mathrm{H}_{2} \mathrm{O}_{2}{ }^{8}$ The leaching solutions are pooled and liquid/liquid solvent extractions with either toluene or carbon tetrachloride/ $\mathrm{HCl}$ are used to produce ${ }^{68} \mathrm{Ge}$ in the final form. The solvent extraction approach recovery yields are $85 \%$ with greater than $99 \%$ radiopurity, and the average ${ }^{68} \mathrm{Ge}$ radioactivity concentrations was $92.96 \mathrm{mCi} / \mathrm{ml}{ }^{11}$ This method works well to produce ${ }^{68} \mathrm{Ge}$ for PET calibration sources. However, the use of the organic solvents such as carbon tetrachloride or toluene is classified by the FDA as Q3C - class 1 and 2 solvents in its Guidance for Industry documentation. ${ }^{12}$ This FDA classification places the solvents in a classification that should not be employed in manufacturing of drugs due to unacceptable toxicity. To obtain FDA approval of the ${ }^{68} \mathrm{Ge} /{ }^{68} \mathrm{Ga}$ generators the initial purification of ${ }^{68} \mathrm{Ge}$ should be performed using non-toxic and non-carcinogenic solvents and meet the properties outlined by both the FDA and the DOE.

According to DOE specifications, the ideal purification of ${ }^{68} \mathrm{Ge}$ would remove all the zinc and cobalt and leave part per million levels of natural Ga. ${ }^{13}$ 
The separation process should recover over $85 \%$ of the ${ }^{68} \mathrm{Ge}$. The purified ${ }^{68} \mathrm{Ge}$ should have a radiochemical concentration greater than $50 \mathrm{mCi} / \mathrm{ml}$, and the product should be in $\sim 0.1 \mathrm{M}$ hydrochloric acid solution. These properties make the final product ideal for use in making the ${ }^{68} \mathrm{Ge} /{ }^{68} \mathrm{Ga}$ medical isotope generator. As mentioned previously, Ge and $\mathrm{Ga}$ tetrachloride are both extremely volatile, ${ }^{10}$ so volume reduction of the $\mathrm{Ge}$ species from dilute $\mathrm{HCl}$ solution to meet the activity concentration requirement would result in contamination issues or loss of product. These requirements for the ${ }^{68} \mathrm{Ge}$ product make separations of ${ }^{68} \mathrm{Ge}$ from gallium difficult.

The challenges associated with the purification of ${ }^{68} \mathrm{Ge}$ were initially examined utilizing a Sephadex ${ }^{\odot}$ G25 column approach using alkaline solutions without a complexing agent. The studies indicated very high germanium concentrations could be obtained, but cobalt retention on Sephadex ${ }^{\odot}$ G25 was identical to germanium. ${ }^{14}$ This approach would require $4-5$ columns to purify ${ }^{68} \mathrm{Ge}$ that meet specifications. Subsequent modification of the method with citrate buffer at $\mathrm{pH} 12.5$ produced ${ }^{68} \mathrm{Ge}$ that meet both FDA and DOE specification for product purity and the method used only one column. ${ }^{15}$ However; when new Sephadex ${ }^{\odot}$ G25 was purchased from Sigma-Aldrich the amount of ${ }^{65} \mathrm{Zn}$ in the purified Ge-68 was outside DOE specifications. As a result different processing methods were developed to produce Ge-68 within DOE specifications, and optimize the time of the separation. We report here the optimization of production scale separation approaches of ${ }^{68} \mathrm{Ge}$ utilizing AG1 and/or Sephadex ${ }^{\odot} \mathrm{G} 25$ resin. 


\section{Methods}

\section{Materials}

All solutions were prepared with $18 \mathrm{M} \Omega$ Millipore water, a Hanna Instruments disposable pH Tester was purchased from Fisher Scientific. Fine Sephadex $^{\odot}$ G25 was purchased from Sigma Aldrich. Econo-Pac $10 \mathrm{ml}$ disposable columns, analytical grade AG1X8 resin were purchased from BIO$\mathrm{RAD}$, and $5 \mathrm{ml}$ disposable centrifuge columns were purchased from Pierce. ICP standards for gallium (Ga), germanium (Ge), cobalt (Co), zinc ( $\mathrm{Zn}$ ) and a 19 element mixed standard were purchased from SPEX CertiPrep (Metuchen, NJ) and used to prepare a set of ICP calibration and QC standards. Gallium metal and other chemicals were purchased from Sigma Aldrich.

\section{Production Scale Separations}

Figure 1 outlines the different processing methods used for the production and purification of ${ }^{68} \mathrm{Ge}$ at BNL from February 2012 to September 2013. Processing methods 2-7 used Sephadex ${ }^{\odot}$ G25 column geometries and bed volumes that are summarized in Table 1 which correspond to the recommended conditions. ${ }^{15}$

Processing method 1: Leaching of the irradiated gallium metal, preparation of the Sephadex ${ }^{\odot}$ G25 column and processing method 1 were described previously. ${ }^{15}$

Processing Method 2: Processing method $1^{15}$ was used with the exception that a $4 \mathrm{ml} \mathrm{BV}$ of fine Sephadex ${ }^{\odot}$ G25 (Sigma) column was used in the separation and the $0.1 \mathrm{M}$ hydrochloric acid elution was fractionated. 
Processing Method 3: The eluted $\mathrm{HCl}$ product fraction 2 from method 2 was passed through a $1 \mathrm{ml}$ column of AG1X8 medium mesh and rinsed with $1 \mathrm{ml}$ of $0.1 \mathrm{M} \mathrm{HCl}$ to produce the final ${ }^{68} \mathrm{Ge}$ product.

Processing Method 4: The pooled leached ${ }^{68} \mathrm{Ge}$ solution was diluted to $1.5 \mathrm{M}$ $\mathrm{HCl}$ and passed through a $5 \mathrm{ml}$ column of AG1X8 (fine mesh, 200-400 mesh). The column was rinsed with $5 \mathrm{ml}$ of $1.5 \mathrm{M} \mathrm{HCl}$ and the eluted $\mathrm{HCl}$ was pooled and added to $125 \mathrm{ml}$ of $1 \mathrm{M}$ sodium citrate, $\mathrm{pH}$ adjusted to 12.5 with $10 \mathrm{M} \mathrm{NaOH}$. The Sephadex ${ }^{\odot}$ G25 separation described for processing method $1^{15}$ was used with a $1 \mathrm{ml} \mathrm{BV}$ of fine Sephadex ${ }^{\circledR} \mathrm{G} 25$ (Sigma) to produce the final product.

Processing Method 5: Processing method $1^{15}$ was used with the exception that a $2 \mathrm{ml} \mathrm{BV}$ of fine Sephadex ${ }^{\odot}$ G-25 (Sigma) was prepared with zinc at $2.5 \mathrm{ppm}$ concentration, and the column was left overnight. The load solution $\left({ }^{68} \mathrm{Ge}\right.$ and 1 M sodium citrate) was modified with $500 \mu$ of 1,000 ppm zinc ICP standard prior to $\mathrm{pH}$ adjusting the solution to 12.5 and performing the separation.

Processing Method 6: The load, washings and $\mathrm{HCl}$ elutions from processing method 5 were combined, $\mathrm{pH}$ adjusted to 12.5 then the ${ }^{68} \mathrm{Ge}$ was purified according to processing method $1^{15}$ with a $2 \mathrm{ml} \mathrm{BV}$ of fine Sephadex ${ }^{\odot}$ G25 (Sigma).

Processing Method 7: The pooled leached ${ }^{68} \mathrm{Ge}$ solution was processed according to method 4 with the exception that $100 \mu \mathrm{l}$ of $1,000 \mathrm{ppm}$ zinc ICP standard was added prior to $\mathrm{pH}$ adjusting the solution to 12.5 . The solution was loaded onto a $2 \mathrm{ml} \mathrm{BV}$ of fine Sephadex ${ }^{\odot} \mathrm{G} 25$. For the recovery of ${ }^{65} \mathrm{Zn}$ the AG1X8 column that retained the ${ }^{65} \mathrm{Zn}$ was rinsed with $1.5 \mathrm{M} \mathrm{HCl}$, and the 
concentration of gallium was tracked by ICP-OES. When the concentration of gallium in the eluted $1.5 \mathrm{M} \mathrm{HCl}$ was below $20 \mathrm{ppm}$ the ${ }^{65} \mathrm{Zn}$ was eluted with 0.01 $\mathrm{M} \mathrm{HCl}$. The solution was concentrated; ${ }^{65} \mathrm{Zn}$ was redissolved in $0.1 \mathrm{M} \mathrm{HCl}$ with a concentration of $10 \mathrm{mCi} / \mathrm{ml}$ and characterized by gamma spectroscopy and ICPOES.

\subsection{Analysis}

Radioactive analysis was performed with a high purity germanium detector, and metal analysis was performed on a Perkin Elmer ICP-MS ELAN DRC or an ICPOES Optima 7300 DV. For both ICP instruments a five point calibration curve was used and checked by three QC samples at the low, middle and high points on the curve. The ICP-MS instrument was tuned to pass the manufacturer's specifications with a Perkin Elmer "smart tune" solution.

\section{Results}

Figure 1, Table 1 \&Table 2 summarize the processing methods, data and results for the seven processing methods. In all separations the concentration of Ga was below the amount from the organic extraction method. In processing methods $1,3,4,6$ and 7 the products meet DOE specifications for purity, radioactive concentration and recoveries of ${ }^{68} \mathrm{Ge}$ were $85-100 \%$. The radioactive amount of ${ }^{65} \mathrm{Zn}$ in fractions 1 and 2 of processing method 2 were $0.93 \mathrm{mCi}$ and $1.3 \mathrm{mCi}$ compared to $0.05 \mathrm{mCi}$ and a non-detectable of similar fractions from processing method 1 . The ${ }^{65} \mathrm{Zn}$ in the samples from processing method 2 resulted in the batch not meeting specifications. The sample was passed through an AG1X8 column (processing method 3), and the eluted solution meet DOE 
specifications. In processing method 5 the Sephadex ${ }^{\odot}$ G25 was prepared with zinc, and this resulted in a prolonged elution time and minimal retention of ${ }^{68} \mathrm{Ge}$. Processing methods 6 and 7 utilize a cold spike of zinc metal to the ${ }^{68} \mathrm{Ge}$ citrate solution prior to loading on the Sephadex ${ }^{\odot}$ G25 column. The cold zinc spike competed with ${ }^{65} \mathrm{Zn}$ retention on the Sephadex ${ }^{\odot} \mathrm{G} 25$ column; the result is the reduction of ${ }^{65} \mathrm{Zn}$ in the product. The purified ${ }^{68} \mathrm{Ge}$ from both methods contained no visual peaks for gamma rays from ${ }^{65} \mathrm{Zn}$, and the amount of ${ }^{65} \mathrm{Zn}$ was below the detection limits $(0.003 \mu \mathrm{Ci})$ of the HPGE radiation detector. The corresponding zinc levels are below the lower limit of quantification (LLOQ) by ICP-OES (0.05 ppm). ICP-OES analysis of processing methods 1, 3, and 4 indicated the purified ${ }^{68} \mathrm{Ge}$ contained 4-40 ppm gallium. In processing methods 6 \& 7 gallium was below the LLOQ $(0.01 \mathrm{ppm})$ of the ICP-OES, which may be caused by the zinc spike in both methods. In processing methods 6 and 7 germanium was the only element detected. ${ }^{65} \mathrm{Zn}$ purification: In processing method $7^{65} \mathrm{Zn}$ was quantitatively recovered, and the concentration of zinc and gallium was 112.6 and $42 \mathrm{ppm}$. The specific activity of ${ }^{65} \mathrm{Zn}$ was $82 \mathrm{mCi} / \mathrm{mg}$, and the radiochemical concentration was $9.19 \mathrm{mCi} / \mathrm{ml}$. The characteristics of the purified ${ }^{65} \mathrm{Zn}$ were within the DOE specifications of $>1 \mathrm{mCi} / \mathrm{ml}$ and a radiopurity $>99 \%$.

\section{Discussion}

This paper optimizes the purification of ${ }^{68} \mathrm{Ge}$ and ${ }^{65} \mathrm{Zn}$ using a leaching step followed by purification of the leached germanium solution by an AG1X8 and/or Sephadex ${ }^{\odot}$ G25 resin. Processing method 1 was initially successful and produced ${ }^{68} \mathrm{Ge}$ that meet DOE specifications. ${ }^{15}$ However, switching 
manufacturers of Sephadex ${ }^{\odot}$ G25 from Pharmacia to Sigma resulted in a noticeable change in the amount of ${ }^{65} \mathrm{Zn}$ in the purified ${ }^{68} \mathrm{Ge}$ and caused the product to fail DOE specifications. Subsequent processing methods were performed to eliminate ${ }^{65} \mathrm{Zn}$ from the product, reduce the processing time or allow a purification of both ${ }^{65} \mathrm{Zn}$ and ${ }^{68} \mathrm{Ge}$. Processing methods 3, 4, 6 and 7 could be used to produce ${ }^{68} \mathrm{Ge}$ that meet DOE specifications. Processing method 3 is not recommended as performing the AG1X8 column after the Sephadex ${ }^{\odot}$ G25 column adds 1-1.5 hours to the processing time. The method required a small AG1X8 column, and the potential to dilute the purified ${ }^{68} \mathrm{Ge}$ below $50 \mathrm{mCi} / \mathrm{ml}$ and out of DOE specifications. When the AG1X8 column was performed before the Sephadex ${ }^{\odot}$ G25 column a larger AG1X8 column was used and only 15 minutes were added to the separation time (processing methods 4 and 7 ). This approach allows the recovery and purification of ${ }^{65} \mathrm{Zn}$ from ${ }^{68} \mathrm{Ge}$ according to traditional methods. ${ }^{16}$ If ${ }^{65} \mathrm{Zn}$ is a waste product then processing method 6 is the best method and only a Sephadex ${ }^{\odot}$ G25 column would be needed to purify the leached ${ }^{68} \mathrm{Ge}$.

Specific optimized column geometries and processing methods allowed very high ${ }^{68} \mathrm{Ge}$ activity concentrations where germanium was the only detected element. Ideally the purification should be performed with greater than $600 \mathrm{mCi}$, so a $4 \mathrm{ml} \mathrm{BV}$ of Sephadex ${ }^{\complement} 25$ can be used and the column separation time would be reduced to 2-3 hours. A 4 ml BV of Sephadex ${ }^{\circledR} \mathrm{G} 25$ was not used with less than $600 \mathrm{mCi}$ as more fractionation is needed of the ${ }^{68} \mathrm{Ge}$ eluted in $0.1 \mathrm{M}$ 
$\mathrm{HCl}$. Each fraction would require a dose measurement to identify ${ }^{68} \mathrm{Ge}$ to pool, which would lead to higher radiation doses to personnel.

\section{Conclusions}

This paper focuses on the development of a production scale separation of ${ }^{68} \mathrm{Ge}$ for use in a ${ }^{68} \mathrm{Ge} /{ }^{68} \mathrm{Ga}$ generator. The aqueous chemistry approaches with the resins was able to produce purified ${ }^{68} \mathrm{Ge}$ that meets both FDA and DOE specifications and was implemented in production of ${ }^{68} \mathrm{Ge}$. The processing methods were used to process $2.5 \mathrm{Ci}$ of ${ }^{68} \mathrm{Ge}$ at $\mathrm{BNL}$ in 2012-2013. The implementation of the processing methods were used to produced ${ }^{68} \mathrm{Ge}$ at the highest radioactive concentrations $(>250 \mathrm{mCi} / \mathrm{ml})$ and with the highest purity compared to any other approach. Processing method 7 has been implemented for the purification of both ${ }^{68} \mathrm{Ge}$ and ${ }^{65} \mathrm{Zn}$ and will be used for future purifications.

\section{Acknowledgements}

This study was supported by funding provided by the Department of Energy, Office of Nuclear Physics, subprogram Isotope Development and Production for Research and Applications. Special thanks to the Brookhaven National Laboratory isotope production team: Anna Goldberg, Slawko Kurczak, Elizabeth Korach, Lisa Muench, Joseph O'Conor, Cleve Dodge, Dmitri Medvedev.

\footnotetext{
${ }^{1}$ Fitzsimmons, J., Atcher, R., Method for the chemical separation of Ge-68 from its daughter Ga-68. US Patent \# 2009/0001283 A1, January 1, 2009.

${ }^{2}$ Rosch, F., 2013. Past, present and future of ${ }^{68} \mathrm{Ge} /{ }^{68} \mathrm{Ga}$ generators. Appl. Radiat. Isot. 76, 24-30.
} 
${ }^{3}$ Gallium-68 DOTATOC Receives FDA Orphan Drug Designation for Neuroendocrine Tumor Management. SNMMI press release. November 18, 2013.

${ }^{4}$ Banerjee, S., Pomper, M., 2013. Clinical applications of Gallium-68. Appl. Radiat. Isot. 76, 2-13.

${ }^{5}$ Smith, D., Breeman, W., Sims-Mourtada, J., 2013. The untapped potential of gallium 68-PET: The next wave of ${ }^{68} \mathrm{Ga}$-agents. Appl. Radiat. Isot. 76, 14-23.

${ }^{6}$ Schultz, M., Mueller, D., Baum, R., Watkins, G., Breeman, W., 2013. A new automated $\mathrm{NaCl}$ based robust method for routine production of gallium-68 labeled peptides. Appl. Radiat. Isot. 76, 46-54.

${ }^{7}$ Eberlein, U., Lassmann, M., 2013. Dosimetry of $\left[{ }^{68} \mathrm{Ga}\right]$-labeled compounds. Appl. Radiat. Isot. 76, 70-74.

${ }^{8}$ Meinkin, G., Kurczak, S., Mausner, L., Kolsky, K., Srivastava, S., 2005. Production of high specific activity ${ }^{68} \mathrm{Ge}$ at Brookhaven National Laboratory. J. Radioanal. Nucl. Chem. 263, 2, 553-557.

${ }^{9}$ Roesch, F., Filosofov, D., 2010 Production, radiochemical processing and quality evaluation of ${ }^{68} \mathrm{Ge}$. IAEA radioisotopes and radiopharmaceuticals series., No.2. 11-30.

${ }^{10}$ Mirzadeh, S., Lambrecht, R., 1996. Radiochemistry of Germanium. J. Radioanal. Nucl. Chem. 202, 1-2, 7-102.

${ }^{11}$ Batch Records of Germanium production at the Isotope production group, Brookhaven National Lboratory, Upton NY Number of batches $=21$ (2/20087/2011).

${ }^{12}$ FDA Guidance for Industry Q3C-Tables and lists November 2003.

${ }^{13}$ Department of Energy specifications for Ge-68: Ge-68 in $0.1 \mathrm{M} \mathrm{HCl}$, radiochemical concentration $>10 \mathrm{mCi} / \mathrm{mL}$, radiochemical purity $>99 \%$. From: http://www.isotopes.gov/catalog/product.php?element=Germanium\&type=rad\&ra d product index $=21$.

${ }^{14}$ Fitzsimmons, J., Mausner, L., 2015. Evaluation of materials for the separation of germanium from gallium, zinc and cobalt. In press Journal of Chemistry and Chemical Engineering. 


\begin{abstract}
${ }^{15}$ Fitzsimmons, J., Mausner, L., 2014. Development of a production scale purification of Ge-68 from irradiated gallium metal. Radiochim. Acta. ISSN (Online) 2193-3405, ISSN (Print) 0033-8230, DOI: 10.1515/ract-2014-2306.

${ }^{16}$ Medvedev, D., Mausner, L., Meinken, G., Kurzak, S., 2009. Recovery of ${ }^{65} \mathrm{Zn}$ from waste solutions from gallium targets at Brookhaven Linac Isotope Producer J. Radioanal. Nucl. Chem, 280, 137-139.
\end{abstract}


Table 1. Summary of methods/results/DATA for ${ }^{68}$ Ge production runs at BNL from 02/2012 - 09/2013.

\begin{tabular}{|c|c|c|c|c|c|c|c|}
\hline $\begin{array}{l}\text { Processing } \\
\text { Method }\end{array}$ & $1^{15}$ & 2 & 3 & 4 & 5 & 6 & 7 \\
\hline \multicolumn{8}{|c|}{ Leached } \\
\hline${ }^{68} \mathrm{Ge}(\mathrm{mCi})$ & 300 & 610 & \multirow{2}{*}{$\begin{array}{l}\text { Used } \mathrm{HCl} \text { product } \\
\text { from method } 2\end{array}$} & 257 & 440 & \multirow{2}{*}{$\begin{array}{l}\text { Load and } \mathrm{HCl} \\
\text { solutions } \\
\text { from method } \\
5\end{array}$} & 410 \\
\hline${ }^{65} \mathrm{Zn}(\mathrm{mCi})$ & 70 & 202 & & 62 & 125 & & 118 \\
\hline \multicolumn{8}{|c|}{ Method } \\
\hline $\begin{array}{c}\text { Sequence } \\
\text { [Sephadex } \\
\text { Column: BV- } \\
\text { Col.-Mesh] }\end{array}$ & $\begin{array}{c}\text { Sephadex }^{\mathrm{a}} \\
{[1-10-\mathrm{F}]} \\
\text { (Phamacia) }\end{array}$ & $\begin{array}{l}\text { Sephadex } \\
{[4-30-F]}\end{array}$ & Sephadex, AG1 & $\begin{array}{c}\text { AG1, } \\
\text { Sephadex } \\
{[1-10-\mathrm{F}]}\end{array}$ & $\begin{array}{c}\mathrm{Zn}, \mathrm{Zn} \text { preloaded } \\
\text { Sephadex } \\
{[2-5-\mathrm{F}]}\end{array}$ & $\begin{array}{c}\text { Zinc, } \\
\text { Sephadex } \\
{[2-5-\mathrm{F}]}\end{array}$ & $\begin{array}{c}\text { AG1, Zinc, } \\
\text { Sephadex } \\
{[2-5-F]}\end{array}$ \\
\hline $\begin{array}{l}\text { Processing } \\
\text { Method } \\
\text { Comments }\end{array}$ & & $\begin{array}{c}\text { Sigma } \\
\text { different } \\
\text { retention of } \\
\text { Zinc compared } \\
\text { to Pharmacia } \\
\text { Sephadex }\end{array}$ & $\begin{array}{l}\text { AG1 adds } \sim 1-1.5 \\
\text { hr smaller column, } \\
\text { slow flow }\end{array}$ & $\begin{array}{l}\text { AG1 adds } \sim 30 \\
\text { min }\end{array}$ & $\begin{array}{l}\text { Poor retention of } \\
\text { Ge, Low Ge } \\
\text { recovery }\end{array}$ & $\begin{array}{l}\text { Easiest } \\
\text { method }\end{array}$ & $\begin{array}{l}\text { Zn-65 recovered } \\
\text { from AG1, } \sim 4 \mathrm{hrs} \\
\text { for Sephadex load, } \\
\sim 1 \mathrm{hr} \text { for rinse \& } \\
\text { elute }\end{array}$ \\
\hline \multicolumn{8}{|c|}{ Load Solution after column } \\
\hline${ }^{68} \mathrm{Ge}(\mathrm{mCi})$ & $<1 \mathrm{mCi}$ & 17 & Same as method 2 & NA & $\sim 400$ & 40 & NA \\
\hline${ }^{65} \mathrm{Zn}(\mathrm{mCi})$ & NA & 200 & Same as method 2 & NA & NA & NA & NA \\
\hline
\end{tabular}

a-fine Sephadex G25 was from pharmacia. Processing methods 2-7 used fine Sephadex G25 from Sigma. Column: 1-10 is $1 \mathrm{ml}$ bed volume in a Bio-Rad $10 \mathrm{ml}$ disposable column. 2-5 is $2 \mathrm{ml}$ bed volume in a $5 \mathrm{ml}$ disposable centrifuge columns (Pierce). 4-30 is a $4 \mathrm{ml}$ bed volume in a Bio-Rad $30 \mathrm{ml}$ disposable column. Mesh: F fine. NA Not analyzed. 
Table 2. Product data for ${ }^{68} \mathrm{Ge}$ production runs at BNL from 02/2012 - 09/2013.

\begin{tabular}{|c|c|c|c|c|c|c|c|c|c|}
\hline Processing Method & $\begin{array}{l}\text { DOE } \\
\text { specs. }\end{array}$ & $\begin{array}{c}\text { Organic } \\
\text { extraction }\end{array}$ & $1^{15}$ & 2 & 3 & 4 & 5 & 6 & 7 \\
\hline Sequence & & Reference 3 & $\begin{array}{l}\text { Sephadex }{ }^{a} \\
\text { (Phamaceia) }\end{array}$ & $\begin{array}{l}\text { Sephadex } \\
\text { (Sigma) }\end{array}$ & $\begin{array}{c}\text { Sephadex, } \\
\text { AG1 }\end{array}$ & $\begin{array}{c}\text { AG1, } \\
\text { Sephadex }\end{array}$ & $\begin{array}{c}\mathrm{Zn}, \mathrm{Zn} \\
\text { preloaded } \\
\text { Sephadex } \\
\end{array}$ & $\begin{array}{c}\text { Zinc, } \\
\text { Sephadex }\end{array}$ & $\begin{array}{c}\text { AG1, } \\
\text { Zinc, } \\
\text { Sephadex }\end{array}$ \\
\hline $\begin{array}{l}\text { \% Ge recovery in } \\
\mathrm{HCl} \text { form }\end{array}$ & $>80$ & 85 & $1.6 / 86.6 / 20$ & 97 & 99 & 99 & $10 \%$ & $90 \%$ & $99 \%$ \\
\hline Radiopurity Ge (\%) & 99 & $100 \%$ & 100 & NA & 99.7 & 100 & NA & 100 & 100 \\
\hline $\begin{array}{c}\text { Ge activity Fr1/2/3 } \\
\text { mCi }\end{array}$ & --- & $130-2917$ & $5 / 260 / 60$ & $128 / 465^{\mathrm{c}} /<5$ & $465^{\mathrm{c}}$ & 257 & 40 & $140 / 274 /<5$ & 408 \\
\hline $\begin{array}{c}\text { Conc Ga Fr } 1 / 2 / 3 \\
\text { ppm }\end{array}$ & --- & Ave 63 & $\mathrm{NA} / 42 / 40$ & NA & 9.56 & 4.00 & NA & $31.7 / \mathrm{ND} / \mathrm{NA}$ & ND \\
\hline $\begin{array}{c}\text { Activity } \\
{ }^{65} \mathrm{Zn} \mathrm{Fr} 1 / 2 / 3(\mathrm{mCi}) \\
\end{array}$ & --- & ND & $0.05 / \mathrm{ND} / \mathrm{ND}$ & $0.93 / 1.3$ & ND & ND & NA & ND & ND \\
\hline $\begin{array}{c}\text { Total Vol or mass } \\
\text { Fr } 1 / 2 / 3 \text { or product }\end{array}$ & --- & $2.32-29.2 \mathrm{ml}$ & $1 / 1 / 1(\mathrm{ml})$ & $4 / 5 / \mathrm{NA}(\mathrm{ml})$ & $6.116(\mathrm{~g})$ & $3.25(\mathrm{~g})$ & NA & $5.795(\mathrm{~g})$ & $2 / 2 / 2 \mathrm{mls}$ \\
\hline $\begin{array}{c}\text { Ge-68 Conc. } \\
(\mathrm{mCi} / \mathrm{ml} \text { or } \mathrm{mCi} / \mathrm{g})\end{array}$ & $\begin{array}{c}>10 \\
\mathrm{mCi} / \mathrm{ml}\end{array}$ & & $5 / 260 / 60$ & ND & 76 & 79 & ND & 71.44 & 204 \\
\hline $\begin{array}{c}\text { Specific activity } \\
(\mathrm{mCi} / \mathrm{mg})\end{array}$ & ---- & $1337-2012^{\mathrm{a}}$ & 3818 & NA & 1454 & 3755 & NA & $1909^{\mathrm{a}}$ & $1622^{\mathrm{a}}$ \\
\hline $\begin{array}{c}\text { Out of specs - } \\
\text { problem }\end{array}$ & & $\begin{array}{c}\text { Organic } \\
\text { solvent }\end{array}$ & $\begin{array}{l}\text { Fr } 1 \mathrm{Ge}-68 \\
\text { conc. to low }\end{array}$ & $\begin{array}{l}\text { High Zn-65 } \\
\text { activity }\end{array}$ & ---- & ---- & $\begin{array}{l}\text { Ge-68 conc } \\
\text { too low }\end{array}$ & ---- & $\begin{array}{c}\mathrm{Fr} 1,3 \\
<5 \mathrm{mCi}\end{array}$ \\
\hline Within spec & & --- & Fr $2 \& 3$ & none & $\begin{array}{c}\text { AG1 } \\
\text { elution }\end{array}$ & Fr $2 \& 3$ & none & Fr $1 \& 2$ & Fr 2 \\
\hline
\end{tabular}

ND-not detected, NA-no analyzed performed, a-Analysis by ICP-OES, other analysis performed by ICP-MS. 
Target Material: Ga metal in a niobium capsule. Nuclear Production Reaction: ${ }^{69} \mathrm{Ga}(\mathrm{p}, 2 \mathrm{n}){ }^{68} \mathrm{Ge} ;{ }^{71} \mathrm{Ga}(\mathrm{p}, 4 \mathrm{n}){ }^{68} \mathrm{Ge}$

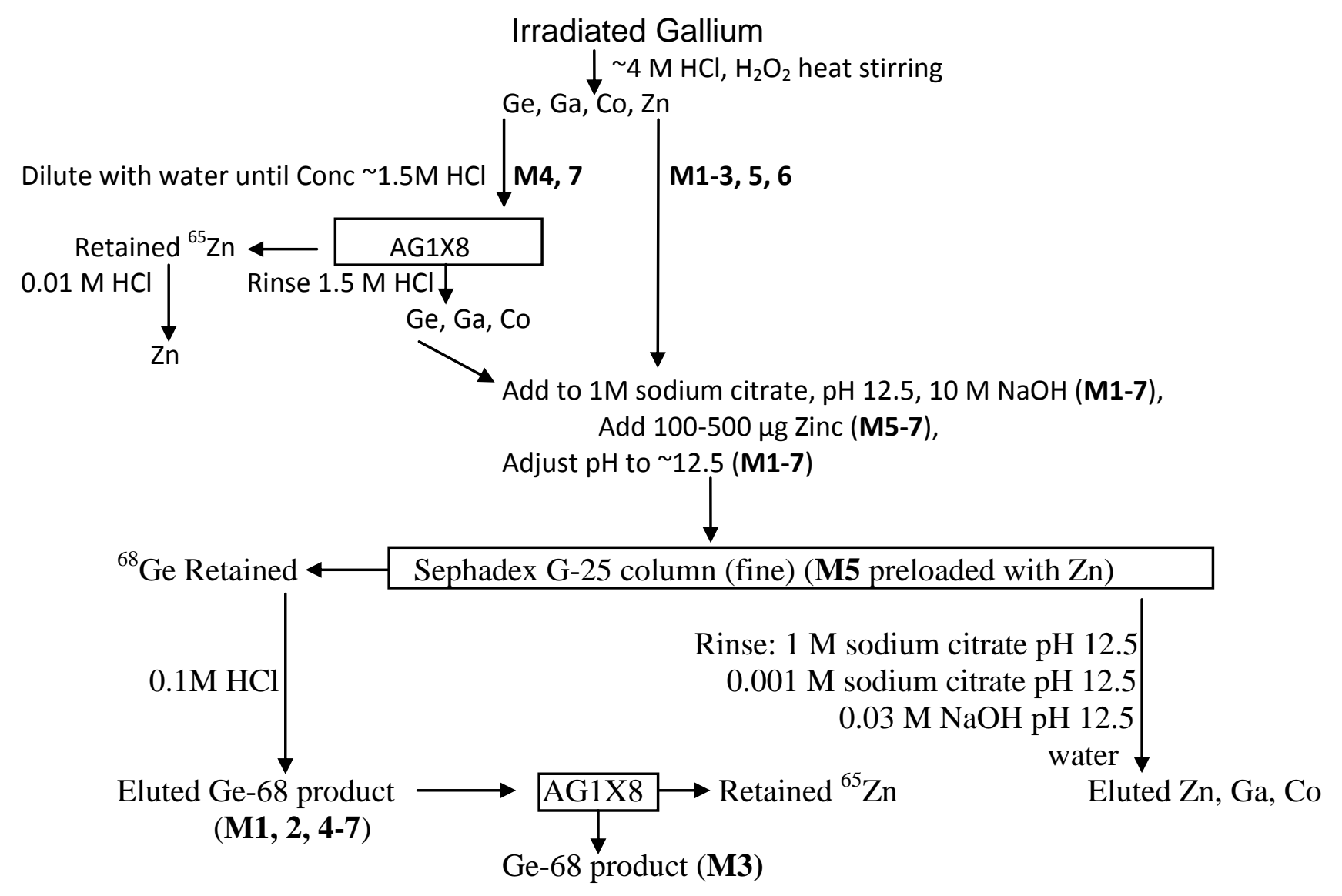

Figure 1. Flow chart for processing methods 1-7 used in Ge-68 production. $(\mathrm{M})=$ processing method 